\title{
UPAYA MENINGKATKAN KETRAMPILAN MOTORIK HALUS MELALUI METODE BERMAIN PLASTISIN PADA ANAK USIA DINI
}

\author{
Oleh \\ Ni Ketut Suci \\ Kepala TK Dirgayusa Ungasan Kuta Selatan \\ sucitkdy@gmail.com
}

\begin{abstract}
The notion that playing gadgets is a present for the early childhood and the habits of parents to facilitate their children with gadgets will reduce the function and role in parenting to be an option for today's parents. On the basis of comfort for parents of children's activities are sometimes considered disturbing, parents take steps and solutions that he thinks are powerful to make his son silent, by giving him a tablet, iPhone, HP and other similar digital goods. The use of these items if not balanced with controls, clear rules and consequences may have an adverse effect on the development of fine motor skills of the child. Fine motor activity is an activity that involves small muscles such as fingers. The use of digital goods only involves one of the child's fingers, such as the thumb or forefinger that is aided by its development. This will be a problem for the child as they enter the preschool age. When given the activities that must involve all his fingers, not infrequently the children whose fingers are very stiff and even weak, so need the help of teachers to complete the task well. Based on the problem, this study aims to find an alternative problem solving as an effort to improve the fine motor skills of children in Dirgayusa kindergarten. Related to that, the researchers chose the method of "Play Plastisin". Plasticin play activities can involve the fingers of the child as a whole and coordinated. The movement includes squeezing, grinding, clenching, squeezing and so forth. This activity is performed by the child repeatedly and is very useful to train the flexibility and strength of the muscles of his fingers for the preparation of more complex activities. After the application of this method of plastisin play, several benefits can be obtained significantly, such as: a) Flexibility, strength and fine motor skills of the child increases. b) The child is easier and more confident to perform more complex delicate motor activities c) Teachers more easily in the guidance and mastery of the class d) Teachers are increasingly motivated in finding a breakthrough or choose a method of learning that can solve problems / difficulties of learning children, e) Schools become more dynamic and inspirational as new ideas emerge.f) Parents increasingly trust to entrust their children, because teachers are able to find solutions to learning difficulties encountered and children still get joy in learning.
\end{abstract}

Keywords: Soft Motoric, Play Plasticine

\begin{abstract}
Abstrak
Anggapan bahwa bermain gadget adalah kekinian bagi anak usia dini dan kebiasaan orang tua memfasilitasi anaknya dengan gadget akan mengurangi fungsi dan perannya dalam pengasuhan menjadi pilihan bagi orang tua jaman sekarang. Atas dasar kenyamanan bagi orang tua dari aktivitas anak yang terkadang dianggap mengganggu, orang tua mengambil langkah dan solusi yang menurutnya ampuh untuk membuat anaknya diam, yakni dengan memberinya tablet, iPhone, HP dan barang digital sejenis lainnya. Penggunaan barang-barang sejenis ini apabila tidak diimbangi dengan control, aturan dan konsekuensi yang jelas bisa membawa dampak yang kurang baik bagi perkembangan ketrampilan motorik halus anak. Aktivitas motorik halus adalah kegiatan yang melibatkan otot-otot kecil seperti jari jemari.
\end{abstract}

PRATAMA WIDYA, VOL. 3, NO. 1, 2018 
Penggunaan barang-barang yang serba digital hanya melibatkan salah satu jari anak,misalnya jempol atau telunjuk saja yang dibantu perkembangannya. Hal ini akan menjadi masalah bagi anak ketika mereka memasuki usia prasekolah. Ketika diberikan kegiatan yang harus melibatkan semua jemarinya, tidak jarang anak yang jari-jarinya sangat kaku bahkan lemas, sehingga perlu bantuan guru untuk menyelesaikan tugas dengan baik. Berdasarkan masalah tersebut, penelitian ini bertujuan untuk mencari alternatif pemecahan masalah sebagai upaya untuk meningkatkan ketrampilan motorik halus anak di TK Dirgayusa. Berkaitan dengan hal itu,peneliti memilih metode "Bermain Plastisin". Kegiatan bermain plastisin dapat melibatkan jari jemari anak secara keseluruhan dan terkoordinasi. Gerakan tersebut meliputi meremas, menggiling, mengepal, memencet dan lain sebagainya. Kegiatan ini dilakukan oleh anak secara berulang-ulang dan sangat bermanfaat untuk melatih kelenturan dan kekuatan otot-otot jemarinya untuk persiapan kegiatan yang lebih kompleks. Setelah penerapan metode bermain plastisin ini, beberapa manfaat yang bisa didapatkan secara nyata, seperti: a) Kelenturan, kekuatan dan ketrampilan motorik halus anak meningkat. b) Anak lebih mudah dan lebih percaya diri untuk melakukan aktivitas motorik halus yang lebih kompleks c) Guru lebih mudah dalam melakukan bimbingan dan penguasaan kelas d) Guru semakin termotivasi dalam mencari terobosan atau memilih metode pembelajaran yang dapat memecahkan masalah/ kesulitan belajar anak, e)Sekolah menjadi lebih dinamis dan inspiratif karena banyak timbul gagasan baru. f) Orang tua murid semakin percaya untuk menitipkan anaknya, karena guru mampu mencarikan solusi atas kesulitan belajar yang ditemui dan anak-anak tetap mendapatkan sukacita dalam belajar.

\section{Kata kunci: Motorik Halus, Bermain Plastisin}

\section{PENDAHULUAN}

\subsection{Latar Belakang Masalah}

Belajar melalui bermain adalah cirri khas dunia anak usia dini. Anak akan "mau dan berhasil" apabila yang mereka lakukan membawa mereka pada perasaan senang, gembira, bahagia dan tidak tertekan serta bebas bereksplorasi. Demikian halnya dalam menanamkan konsep apapun terkait dengan 6 (enam) aspek pengembangan yang ada di Taman Kanak-Kanak meliputi : Nilai Agama dan Moral, Sosial Emosional dan Kemandirian, Berbahasa, Kognitif, Fisik Motorik dan Seni, hendaknya senantiasa dikemas dengan kegiatan bermain yang alami dan menyenangkan. Namun seiring berjalannya waktu, disadari atau tidak disadari ada banyak hal yang bergeser bahkan berubah. Ada banyak hal yang alami menjadi instan, ada banyak kebiasaan yang berubah, ada banyak norma yang bergeser dan ada banyak cara yang keliru. Demikian halnya arus globalisasi, dinamika pendidikan dan kemajuan teknologi yang tidak sepenuhnya membawa pengaruh dan dampak positif bagi kita utamanya anak-anak yang merupakan tunas bangsa yang wajib kita kawal perkembangannya dengan baik. Disatu sisi kemajuan teknologi membuat anakanak menjadi "mudah", bisa melakukan dan mendapatkan apapun dengan cara yang cepat. Di sisi lain kemajuan teknologi bisa membuat kita menjadi malas "Malas bepfikir, malas bergerak, dan malas beraktifitas. Inilah yang terjadi pada sebagian besar anak-anak sekarang. Tanpa disadarai kemajuan teknologi seperti penggunaan iPed, HP, maupun alat digital lainnya telah mengurangi 
keaktifan dan koordinasi kerja jemari anak secara keseluruhan. Bagaimana tidak? Karena dengan alat-alat semacam itu anak cendrung menggunakan salah satu jarinya saja seperti jempol dan telunjuk. Dampak dari kebiasaan dan kondisi ini sangat terlihat dan terasa ketika anak memasuki dunia pra sekolah atau Taman Kanak-Kanak, dimana banyak anak yang jemarinya belum trampil, belum lentur, bahkan masih sangat kaku ketika diajarkan teknik memegang pensil yang baik dan benar lalu menggerakkannya. Kondisi ini tidak boleh kita biarkan terjadi pada anak-anak. Jika kita ingin menumbuhkan tunas bangsa unggulan di kemudian hari, kita tidak boleh "Salah Start dan Kalah Start" Mengingat masa peka dimana anak siap secara psikhis untuk menerima segala bentuk stimulasi, muncul dan berkembang sanagat pesat pada usia dini ( $0 \mathrm{~s} / \mathrm{d} 6$ tahun) maka kita sebagai orang dewasa yang berada di sekelilingnya harus segera mencari upaya untuk memperbaikinya.

Sesuai dengan yang diamantkan oleh Undang-Undang Republik Indonesia No. 20 tahun 2003 tentang sistem Pendidikan Nasional dijelaskan bahwa tujuan pendidikan nasional adalah mencerdaskan kehidupan Bangsa dan membangun manusia Indonesia seutuhnya yaitu manusia yang beriman dan bertaqwa pada Tuhan Yang Maha Esa dan berbudi pekerti yang luhur, memiliki pengetahuan dan ketrampilan, kesehatan jasmani dan rohani, kepribadian yang mantap dan mandiri serta tanggung jawab kemasyarakatan dan kebangsaan.
Dari uraian di atas jelas dipaparkan bahwa tugas kita sebagai pendidik utamanya guru dan orang tua, tidak hanya membangun pengetahuannya saja, namun tidak kalah penting membangun ketrampilan fisiknya, termasuk trampil dalam menggunakan anggota tubuhnya secara baik dan benar. Tentunya dibutuhkan kesabaran yang luar biasa dan ketulusan dari seorang guru TK dalam membimbing dan melatih anak-anak secara terus menerus dan berkesinambungan sesuai dengan usia dan tingkat perkembangannya.

Dalam hal ketrampilan motorik halus pada anak kelompok A Semester I TK Dirgayusa Ungasan, Kuta Selatan Kabupaten Badung Tahun Pelajaran 2017/2018 peneliti melihat bahwa kemampuan anak utamanya dalam kelenturan dan koordinasi jemarinya sekitar $50 \%$ belum mencapai indikator ketercapaian yang diharapkan. Melihat kondisi tersebut, akhirnya terpikir oleh peneliti untuk melatih atau meningkatkan kelenturan dan koordinasi motorik halus anak sebelum meningkatkan kemampuannya pada kegiatan yang lebih kompleks, melalui kegiatan bermain plastisin. Karena melalui kegiatan ini anak-anak dilatih menggunakan seluruh jemarinya secara terus menerus sehingga terbentuk koordinasi dan kelenturan untuk kesiapan kegiatan yang lebih kompleks seperti pra menulis atau mencoret dan meniru bentuk lainnya.

\subsection{Identifikasi Masalah}

Masalah - masalah yang mendasari penelitian ini adalah sebagai berikut: 
1. Di awal-awal memasuki pra sekolah kelenturan dan koordinasi jari jemari anak masih sangat kaku dan belum trampil

2. Guru kurang kreatif dan inovatif dalam mencari terobosan dan metode-metode pembelajaran yang efektif dan menyenangkan bagi anak.

\subsection{Tujuan Penelitian}

Tujuan penelitian ini adalah mencari alternatif pemecahan masalah sebagai upaya untuk meningkatkan ketrampilan motorik halus anak sebelum melakukan kegiatan yang lebih kompleks.

\subsection{Strategi Pemecahan Masalah}

Untuk dapat memfasilitasi perkembangan anak secara optimal, seorang guru PAUD tidak cukup hanya memahami karakteristik dan kebutuhan peserta didiknya. Namun gurupun harus kreatif dan inovatif, memiliki kemauan untuk mencari terobosan atau metodemetode yang tepat dan menyenangkan untuk memecahkan setiap masalah pembelajaran yang ditemukan. Berkaitan dengan hal tersebut, peneliti memaksimalkan pemanfaatan plastisin untuk memecahkan permasalahan kelenturan dan koordinasi jari jemari anak yang masih perlu dilatih pada awal-awal memasuki pra sekolah untuk kesiapan mengikuti kegiatan yang lebih kompleks seperti membuat coretan, membuat garis, meniru bentuk dan kegiatan-kegiatan lain yang memerlukan kelenturan dan koordinasi jari jemari.
Plastisin adalah salah satu media pembelajaran yang terbuat dari bahan yang sangat lembut yaitu campuran tepung beras, tepung trigu dan lem serta pewarna makanan yang sangat aman bagi kesehatan anak dan dengan berbagai macam warna yang sangat menarik. Bermain Plastisin adalah kegiatan membuat berbagai macam bentuk sesuai dengan keinginan dan imajinasi anak. Dalam kegiatan ini guru mengkondisikan anak belajar dalam suasana yang nyaman, interaktif, komunikatif dan menyenangkan. Anak dapat digabung menjadi beberapa kelompok kecil, sehingga terjadi komunikasi satu sama lain termasuk saling menceritakan apa yang akan dan sedang mereka bentuk dengan plastisin yang telah dibagikan oleh guru sebelumnya. Peranan guru disini hanya memancing imajinasi anak baik melalui cerita, percakapan, tanya jawab dan memperlihatkan contoh berbagai macam bentuk dari plastisin, seperti bentuk binatang, buah-buahan, monster dan peralatan lainnya. Gurupun mendemonstrasikan cara menggunakan plastisin yang baik dan benar. Selanjutnya guru membebaskan anak berekplorasi dengan membuat berbagai macam bentuk sesuai keinginan dan imajinasinya. Tanpa terasa mereka larut dalam hayalan dan imajinasi mereka masing-masing. Mereka membuat berbagai macam bentuk dengan melibatkan semua jemarinya. Ada kegiatan meremas, ada kegiatan menggiling, ada kegiatan mengepal, ada kegiatan memencet dan lain sebagainya. Kegiatan ini sangat bermanfaat untuk melatih kelenturan dan kekuatan otot- 
otot jemarinya utuk persiapan kegiatan yang lebih kompleks. Sesekali mereka menceritakan apa yang sedang dibuatnya dan atau memberi komentar terhadap apa yang sedang dibuat oleh temannya. Dapat dibayangkan betapa suasana ini sangat menyenangkan. Tanpa disadari sesungguhnyamerekatelah belajar banyak hal. Disamping dapat meningkatkan kelenturan, kekuatan dan koordinasi jari jemarinya, anakpun telah belajar berkomunikasi secara lisan, menanbah perbendaharaan kata, anak belajar mengungkpkan bahasa, anak belajar mengungkapkan pendapat, anak belajar interaksi sosial, anak belajar menghargai hasil karya orang lain dan menciptakan karya seni sendiri. Di akhir kegiatan, guru memberikan kesempatan kepada anak untuk menceritakan ke depan kelas apa yang telah mereka bentuk. Betapa mereka sangat senang dan bangga ketika ibu guru memberikan reward dengan mengatakan "Wah.....hebat sekali...pintar ya... tepuk tangan dong...." Kegiatan ini dapat diulang beberapa kali, dengan merubah seting pelaksanaan misalnya di luar kelas atau halaman terbuka, sampai tercapai indicator yang diharapkan terkait kelenturan dan koordinasi jari jemari anak dan siap untuk melakukan kegiatan yang lebih kompleks misalnya menulis atau meniru bentuk huruf, angka dan lain-lain.

\section{LANDASAN TEORI}

\section{Kemampuan Belajar}

Kemanpuan belajar adalah kemampuan untukmemahami hal-halbaru dan kemampuan untuk menghubungkan aspek-aspek yang ditemui. (Utami
Munandar, 1999, (Modul Mahasiswa S1.UT UPBJJ Denpasas 2007/2011)

Menurut Ali Imron,1996:2-3 (Modul Mahasiswa S1.UT UPBJJ Denpasas 2007/2011) Kemampuan belajar adalah proses perubahan prilaku yang terjadi pada diri seseorang. Perubahan itu dapat terjadi dalam bidang ketrampilan, kebiasaan, sikap, pengertian, aspirasi. Yang jelas, seseorang yang telah mengalami perubahan tersebut, ia tidak seperti keadaan sebelumnya. Ia telah memiliki kemampuan belajar seperti lebih senang, lebih setuju, sudah menyesuaikan diri dan sebagainya. Perbuatan-perbuatan tersebut sudah sejak lama kita kenal, bahkan pada era sekarang hampir semua orang sudah mengenal istilah kemampuan belajar.

\section{Perkembangan motorik halus}

Menurut Kail 2001 (Modul Mahasiswa S1.UT UPBJJ Denpasas 2007/2011) Manusia membutuhkan waktu yang lebih lama untuk matang secara motorik dibandingkan dengan makhluk lain. Manusia menghabiskan 20\% dari seluruh kehidupan masa kanakkanak dan remajanya untuk berkembang secara fisik. Pada perkembangannya seorang manusia, perkembangan motorik khusunya motorik halus memegang peranan yang sama pentingnya dengan perkembangan kognisi, prilaku sosial dan kepribadian. Sejalan dengan berkembangnya fisik motorik seorang anak mereka akan menjadi lebih mandiri. Mereka tidak lagi membutuhkan bantuan orang tuanya untuk menuju suatu tempat dan mengambil barang yang 
diinginkannya. Mereka bahkan dapat terlibat dalam permainan anak seusianya.

\section{Kegiatan Bermain Plastisin}

Plastisin terbuat dari bahan yang sangat lembut yaitu campuran tepung beras, tepung trigu dan lem serta pewarna makanan yang sangat aman bagi kesehatan anak. Bermain Plastisin adalah kegiatan membuat berbagai macam bentuk sesuai dengan keinginan dan imajinasi anak. Bermain Plastisin adalah kegiatan membuat berbagai macam bentuk dengan menggunakan plastisin. Peranan guru disini hanya memancing imajinasi anak baik melalui cerita, percakapan, tanya jawab dan memperlihatkan contoh berbagai macam bentuk dari plastisin, seperti bentuk binatang, buah-buahan, monster dan peralatan lainnya. Tanpa terasa mereka larut dalam hayalan dan imajinasi mereka masing-masing. Mereka membuat berbagai macam bentuk dengan melibatkan semua jemarinya. Ada kegiatan meremas, ada kegiatan menggiling, ada kegiatan mengepal, ada kegiatan memencet dan lain sebagainya. Kegiatan ini sangat bermanfaat untuk melatih kelenturan dan kekuatan otot-otot jemarinya utuk persiapan kegiatan yang lebih kompleks.

\section{PEMBAHASAN}

Ketrampilan motorik halus merupakan salah satu kemampuan dan potensi yang terdapat pada setiap anak. Agar potensi kemampuan tersebut berkembang optimal, maka perlu diberikan dasar-dasar ketrampilan melalui latihan dan pembinaan yang dikemas dalam kegiatan bermain yang menyenangkan. Hal ini juga dilaksanakan pada kemampuan dasar, seperti fisik/ motorik (kasar, halus) berbahasa, kognitif, dan seni. Taman Kanak-kanak merupakan tempat yang tepat untuk mengembangkan kemampuan ketrampilan motorik halus anak sebagaimana yang telah ditetapkan dalam Permendikbud Nomor 137 Tahun 2014 tentang Standar PAUD tentang kemampuan motorik halus minimal anak, yang harus dicapai sesuai dengan usianya dan ditunjang oleh sarana dan prasarana yang memadai.

Dalam Permendikbud No. 146 tahun 2014 tentang Kurikulum 2013 PAUD menjelaslkan bahwa program pengembangan fisik-motorik mencakup perwujudan suasana untuk berkembangnya kematangan kinestetik dalam konteks bermain. dan Permendikbud No. 137 tahun 2014 tentang satandar PAUD menyatakan bahwa pengembangan motorik halus mencakup kemampuan dan kelenturan menggunakan jari dan alat untuk mengeksplorasi dan mengekspresikan diri dalam berbagai bentuk

Sementara itu terjadi bahwa pengembangan motorik halus di Taman Kanak-Kanak, disajikan/disampaikan dengan cara yang kurang menarik dan juga pemilihan media atau metode yang kurang tepat ditambah lagi kebiasaan, pola asuh dan pola didik dalam keluarga sangat jarang memberikan pelatihan yang melibatkan kerjasama jemari secara utuh, anak cendrung menggunakan alat -alat digital seperti laptop, i Ped, HP dan lainlain yang hanya melibatkan kinerja salah 
satu jarinya saja. Sehingga berimplikasi pada kemampuan serta kelenturan dan koordinasi motorik halus anak-anak masih rendah.

Penyajian pengembangan motorik halus seharusnya dikemas sedemikianrupa dengan pemberian kegiatan, metode dan media yang bervariasi seperti pemberian tugas atau demonstrasi sambil bermain sehingga anak melaksanakannya dengan penuh rasa senang dan mendapatkan hasil yang maksimal.

Berdasarkan kerangka teori serta kajian pustaka dari beberapa pakar diatas kemungkinan besar kegiatan belajar/latihan sambil bermain dapat meningkatkan interaksi aktif dan keterlibatan siswa langsung dalam sebuah proses dan dilakukannya sendiri, berimplikasi pada meningkatnya kemampuan motorik halus anak dalam hal ini melalui kegiatan bermain dengan plastisin. Karena dengan mengunakan media plastisin, anak dapat melaksanakan kegiatan yang dapat melatih otot-otot kecil termasuk koordinasi mata, pikiran dan tangannya dalam suasana bermain yang menyenangkan, sehingga anak memperoleh ketrampilan yang berguna untuk perkembangan selanjutnya.

Standard Operating Procedures (S.O.P) nya adalah sebagai berikut:

1. Guru menjelaskan dan bercakapcakap dengan anak tentang kegiatan yang akan dilakukan (sesuai dengan tema yang akan deterapkan)

2. Guru memperkenalkan dan menjelaskan tentang media yang akan digunakan (Plastisin)
3. Guru mendemonstrasikan cara penggunaan media (Plastisin)

4. Guru memperlihatkan beberapa contoh bentuk dari plastisin sambil membahasnya melalui percakapan dengan anak-anak.

5. Guru membagikan media (plastisin) kepada anak-anak

6. Guru memberikan kebebasan dan mempersilahkan anak untuk membentuk sesuai imajinasinya.

7. Guru memberi motivasi kepada anak dengan cara ikut berbaur dengan anak dan membuat bentuk dari plastisin sesuai imajinasi guru, sesekali sambil bercakap-cakap tentang kegiatan yang sedang dilakukan

8. Guru mengamati proses yang dilakukan oleh anak secara individual, focus kepada gerak jemarinya (kekuatan, kelenturan, pelibatan semua jari, kreativitas dan hasil)

9. Guru memberikan pujian kepada anak yang telah berhasil dan memberikan bimbingan kepada anak yang masih memerlukan bantuan.

10. Guru membuat catatan kecil tentang perkembangan anak secara individual, sebagai evaluasi apakah metode bermain plastisin efektif untuk meningkatkan ketrampilan motoric halus anak sesuai dengan indicator yang telah ditetapkan.

11. Guru meminta anak satu persatu menceritakan apa yang telah dibuatnya. Guru memberikan pujian kepada anak. 
Untuk dapat mencapai indicator yang telah ditetapkan, kegiatan ini dilakukan dalam 2 (dua) siklus.

Setiap siklus terdiri dari empat kegiatan pokok yaitu ;

1. Perencanaan

2. Pelaksanaan

3. Obsevasi

4. Refleksi

Deskripsi Pelaksanaan Siklus I dan Siklus II

Perencanaan pada setiap siklus meliputi langkah-langkah perencanaan, pelaksanaan, observasi, evaluasi, dan refleksi.

1. Perencanaan

Pada tahap ini langkah-langkah yang dilakukan adalah :

- Menyiapkan tema yang diajarkan

- Menentukan Kompetensi Dasar,indicator,merumuskan tujuan membuat RPPH

- Menyiapkan instrumeninstrumen penelitian berupa lembar/kriteria penugasan dan lembar observasi.

2. Pelaksanaan/ Tindakan

Pada tahap ini langkah-langkah yang dilakukan adalah :

- Melaksanakan RPPH yang dibuat

- Anak dibagi menjadi 3 kelompok

- Mengenalkan pada anakanak alat dan media yang akan digunakan
- Melaksanakan kegiatan sesuai dengan rentang waktu. - Guru memberikan kesempatan yang seluasluasnya kepada anak untuk melaksanakan tugas secara mandiri sehingga semua anak mampu menyelesaikan dengan baik dan rapi dengan tetap diawasi oleh guru.

3. Observasi/Evaluasi

Pada tahap ini langkah-langkah yang dilakukan adalah :

- Mengamati dan mencatat tindakan/proses yang dilakukan oleh anak, apakah sudah sesuai dengan perencanaan serta mengobservasi perhatian dan aktivitas anak

- Mengevaluasi dan mencatat seluruh kegiatan yang telah dilakukan oleh anak dengan lembar observasi.

4. Refleksi

Langkah ini dilakukan pada akhir siklus sebagai bahan dan pertimbangan hasil pengamatan/ penugasan yang dilakukan pada akhir siklus I berdasarkan hasil observasi dan evaluasi. Hasil refleksi ini dilakukan sebagai dasar memperbaiki dan menyempurnakan perencanaan dan pelaksanaan tindakan pada siklus II. 


\section{Indikator Keberhasilan}

Penetapan indikator keberhasilan sangat diperlukan dalam penelitian ini karena dengan adanya indikator keberhasilan dapat dijadikan dasar untuk menyatakan bahwa tindakan yang dilakukan berhasil atau tidak. Untuk itu indikator keberhasilan dalam penelitian ini adalah "Tindakan dinyatakan berhasil apabila lebih dari 65\% anak dapat meningkatkan kemampuan dalam kegiatan bermain plastisin dan terjadi penurunan frekwensi anak yang tergolong kurang mampu dan belum mampu'. Bila indikator keberhasilan telah tercapai berarti tindakan (siklus) dihentikan dan dinyatakan berhasil.

\section{KESIMPULAN DAN REKOMENDASI}

\subsection{Kesimpulan}

Suasana bermain yang menyenangkan, kebebasan untuk berekplorasi, dan pemilihan media belajar yang tepat sesuai dengan usia dan tingkat perkembangan anak, akan membawa anak penuh pada rasa bahagia. Tanpa mereka sadari bahwa mereka telah berlatih, bahwa mereka sedang belajar, bahwa mereka sedang membangun dan menerima suatu konsep. Disinilah dibutuhkan seorang pendidik yang mau dan mampu memahami karakteristik anak didiknya dan berupaya mencarikan solusi pada kendala dan permasalahanpermasalahan belajar yang ditemui. Salah satunya mampu memilih metode pembelajaran yang efektif dan terutama menyenangkan bagi anak. Metode yang memberikan anak kebebasan untuk bereksplorasi dan pembelajaran yang berpusat pada anak. Peneliti meyakini bahwa pemilihan dan penerapan metode yang tepat dapat menghasilkan proses dan hasil belajar yang efektif. "Penerapan Metode Bermain Plastisin Untuk Meningkatkan Ketrampilan Motorik Halus Pada Anak TK Dirgayusa" diperoleh kesimpulan sebagai berikut:

1. Terjadi peningkatan ketrampilan motorik halus anak

2. Peserta didik mendapat kebebasan untuk bereksplorasi, dan menuangkan imajinasinya dalam sebuah karya.

3. Peserta didik mendapatkan suka cita belajar karena lebih banyak variasi permainan dan teknik pengajaran yang diberikan guru

4. Guru termotivasi dan lebih kraetif untuk senantiasa berupaya mencari solusi pada setiap permasalahan belajar yang ditemui oleh anak

5. Sekolah menjadi inspiratif dan dinamis karena timbul banyak gagasan dan ide yang timbul dalam peningkatan kualitas sekolah

\subsection{Rekomendasi}

Berdasarkan kesimpulan yang terurai diatas, penelitimerekomendasikan: 1. Kepada Staf pendidik TK Dirgayusa untuk mengoptimalkan perannya sebagai pendidik yang selalu bekerja dengan hati dan tulus iklas memberikan pelayanan sesuai dengan kebutuhan anak dan selalu meningkatkan kompetensinya.

2. Kepada seluruh jajaran Yayasan untuk terus memfasilitasi staf 
pendidik dalam kegiatan (PKB) Pengembangan Keprofesian Berkelanjutan yang berdampak pada peningkatan kompetensi guru secara menyeluruh.

Kiranya Penelitian Tindakan Kelas ini dapat memberi inspirasi pada setiap insan pendidik untuk bekerja dengan sungguh-sungguh dan dan tulus iklas. Ketika kita melihat permasalahan atau kesulitan belajar pada anak, yang terpenting adalah pemikiran dan kemauan guru untuk mencari solusi dan memecahkannya secara tuntas, bukan mendiamkan dan apalagi memberikan catatan perkembangan yang fiktip (tidak sesuai dengan kenyataan) Ini tidak boleh terjadi, karena seorang pendidik memiliki tanggung jawab moral pada perkembangan dan kehidupan anak di kemudian hari. Apa yang terjadi pada seseorang setelah remaja nanti adalah merupakan akumulasi dari pola asuh dan pola didik pada saat usia dini. Semoga kesadaran dan ketulusan para Pendidik Anak Usia Dini akan mampu menumbuhkan Tunas Bangsa Unggulan di kemudian hari dan mampu mengantarkan anak pada "Indonesia Emas" yang telah didengungkan bersama

\section{DAFTAR PUSTAKA}

Undang-Undang Republik Indonesia No. 20 tahun 2003 tentang sistem Pendidikan Nasional

Peraturan Mentri Pendidikan dan Kebudayaan RI No 146 tahun 2014 tentang Kurikulum 2013 PAUD

Peraturan Mentri Pendiddikan dan

Kebudayaan RI No 137 tahun 2014 tentang Standar PAUD

Utami Munandar, 1999, Modul Mahasiswa S1.UT UPBJJ Denpasas 2007/2011

Ali Imron,1996:2-3 (Modul Mahasiswa S1.UT UPBJJ 2007/2011 